\title{
Salvation in Acts 16: Meaning and missional implication derived from the sociohistorical method
}

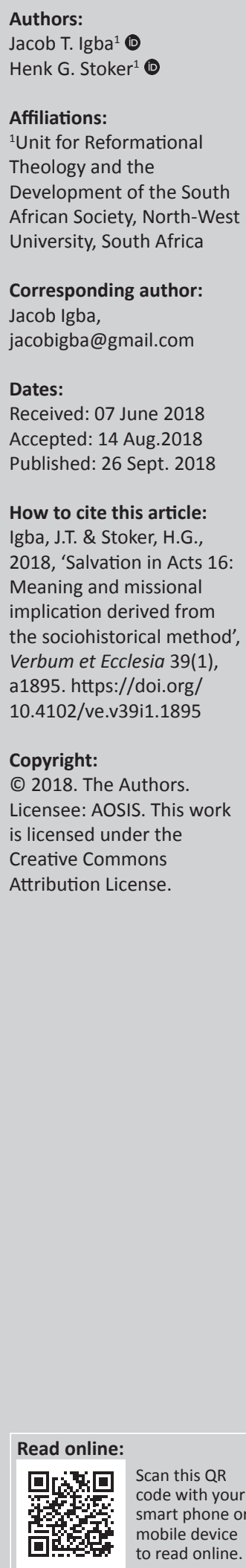

In Acts 16:17, a slave girl proclaims: 'these men are the servants of the Most High God who have come to show a way of salvation!' The Philippian jailer in Acts 16:30 asks, 'What must I do to be saved?' What do they have in common regarding their understanding of the meaning of salvation? How is it similar or different from the understanding of salvation in Africa? Are these in line with the salvation narrative aim of Luke in Acts 16? Through the sociohistorical method, this paper explores the Greco-Roman context of the slave girl and the jailer. In this process, a contextual similarity between the Greco-Roman context and the African context is identified and the impact of these contexts on the understanding of the meaning of salvation is examined. Placed in conversation with the Lukan meaning of salvation in the passage, an alternative meaning of salvation emerges, along with implications for the Greco-Roman and African contexts.

Intradisciplinary and/or interdisciplinary implications: This article shows interdisciplinarity by an engagement with a theological concept through the utilisation of the sociohistorical method in generating meaning and understanding of a New Testament text. It navigates the disciplines of New Testament, Biblical Studies, Mission and Apologetics.

\section{Introduction}

When the slave girl in Acts 16 proclaims that 'these men are the servants of the Most High God who have come to show a way of salvation', an understanding of the general Greco-Roman condition and her particular sociohistorical situation raises the question as to the meaning of the salvation that she spoke about. Similar questions come to mind when one considers the Philippian jailer's question: 'What must I do to be saved?' Is it possible that their understandings of salvation reflect or differ from the Lukan salvation theme? Are there implications that could be drawn from the discovered meaning, especially for the growing communities of Jesus followers in the African context?

In recent years, several examples of the use of approaches to Luke-Acts that differ from the conventional exegetical modes of analysis have emerged among scholars studying the book of Acts. Neyrey (1991), in his book The social world of Luke-Acts: Models for interpretation, highlights various approaches by means of which scholars pay attention to the analysis of the social world of the text. Another example is the six-volume work The Book of Acts in its first-century setting (Winter \& Clarke 1993). Its major feature is to explore the historical and social context of Acts. This has set the stage for exploring the book of Acts from newer angles. ${ }^{1}$ Scholars generally agree that the theme of salvation is recurrent in Luke-Acts and that it is noted as a major theme (Bovon 2006; Marshall 1971; Witherington 1998). What remains lacking in these works, however, is an in-depth exploration in a focused and sustained manner by utilising the sociohistorical approach to the meaning of salvation as portrayed in the narrative of Acts 16.

Apart from the key Luke-Acts scholars highlighted above, African theologians have also taken note of the importance of the subject of salvation to African Christianity and the need for a deeper engagement with the subject.

Adeyemo (1997) and Mbiti (1986) are in agreement about the importance of a deeper understanding of the notion of salvation, especially in an African context. Mbiti (1986:134) points out that even though the term 'salvation' frequently occurs in talks, writings and preaching in African Christianity, a critical and careful study of salvation still remains lacking. The term is considered very important but not sufficiently used by African theologians. An engagement with the concept

1.Green (2010), in Methods for Luke, also highlights a number of approaches recently employed in approaching Luke-Acts, which includes historical criticism, feminism, narrative criticism and a Latino perspective. 
of salvation, especially from a sociohistorical point of view, remains lacking as shown in some more recent discussions by African theologians on the concept (Adelakun 2011; Brand 1999).

In a recent study, Magezi and Igba (2018) point out the difficulty and complexity African theologians are facing in engaging biblical texts from African perspectives. They attribute it largely to lack of clear methodological frameworks. They also note the need for the African perspectival approach to be more rooted in the Bible and explore methodological frameworks that situate African perspectival approaches in conversation with global theological or biblical discourse. A consideration of how African biblical scholars have engaged with the interpretation of the book of Acts confirms the difficulty and reveals that a significant number of African biblical scholars that engage in the interpretation of the book of Acts have left out Acts 16, especially from a sociohistorical perspective. There is evidence of focused engagement by African scholars, mostly with Acts 3 and Acts 17, as seen from the work of Manus (1985), Onwu (1988), Isizoh (1998) and Speckman (1999), without substantially engaging with the subject of salvation according to Acts 16. Speckman (1999) stands out among the listed authors based on the fact that he engages the subject of salvation substantially in his thesis. ${ }^{2}$ However, his engagement approaches the subject of salvation from the angle of the healing episode of Acts 3:1-10 and not Acts 16.

In his thesis, Speckman (1999) focuses on the healing episode of Acts 3:1-10. According to Speckman (1999:14-15), his main concern centres around interpreting the passage in view of its value for proposing a New Testament theology of development, with the South African context in mind. This, according to him, is in keeping with the emerging biblical interpretive trend in South Africa concerned with social and economic issues in the Bible and the relevance of these for today. In this sense, Speckman's thesis differs from the driving concern of this article. Though his views remain important to engage with at points, it does not sufficiently address the concern of this paper.

The validity of interpreting the passage and drawing out implications for African Christianity lies in the contextual similarity between the trend of growing communities of followers of Jesus in Acts and in Africa. The proverbial shift in the centre of gravity of Christianity from the West to the Global South continues to dominate missiological and theological discussion and is well accounted for in the works of Walls (2002), Jenkins (2002), Balcomb (2011) and others; this growth has been variously attested to in Africa. Similar in some ways to the book of Acts, the advance of Christianity in Africa is encountering various pre-existing cultures, understandings and possibly long-held views about salvation.

The narrative of Acts 16 in particular also indicates some contextual similarity with the African context: the expression

2. His thesis raises important points relating to salvation that may need to be explored further. of the fear of death by the jailer in Acts 16 is also not strange in the African religious experience, where the fear of death and dying is widespread. ${ }^{3}$ Furthermore, oracular divination such as carried out by the slave girl is not a strange occurrence. As the passage about the slave girl indicates, her owners are displeased by the encounter, which makes them lose the power and proceeds of divination from the slave they own. They see nothing wrong in what she has been doing but see everything wrong with countering her oracular abilities. The sociohistorical method seems most suited for the aim of this article as discussed below.

\section{Methodology Justification for approaching the text}

The broad framework of the sociohistorical method as described by Meeks (2003), Malherbe (1983) and Garrett (1992) is utilised in this article. The method focuses on the social, economic, legal, cultural and religious factors and how they influence the understanding and meaning of a specific text. As Meeks explains, sociohistorical study of the New Testament is an interpretive approach that takes seriously the first-century social world of the early Christians and the biblical text, in order to 'construct interpretation and to criticise constructions'. Because of the multidimensional nature of this method, it accommodates and complements a combination of related methods such as the theological method in the task of interpretation of a biblical text. The method therefore suits the overall objective of this paper. The sociohistorical approach enables a credible reconstruction of the meaning of the text, bearing in mind the perspective of the author as well as the actual and authorial audiences. Following Rabinowitz (1977:121-141) and Talbert (2003:14-18), four categories of reading audiences for a text have been identified: (1) the 'actual audience', referring to those initially physically reading or listening to the text; (2) the 'authorial audience', referring to those who the author intends the writing for initially - even though they may not be physically present and listening to the author, they share common background knowledge presumed in the text; (3) the 'narrative audience', referring to the audience that are engaging the author's narration from a perspective of a differing background and lacking in the common knowledge presumed in the narrative; and (4) the 'ideal narrative audience', which refers to an audience that accepts the author's presumed perspective regardless of the perspective of the actual and authorial audiences. In most cases, the fourth category of audience hardly pays attention to the other perspectives and lacks the benefit of the possibility of an enriching or differing insight.

\section{Validity for the African context}

An engagement with the narrative in Acts 16 today excludes us from being either the actual or the authorial audience. It places upon us the burden of making a choice to function

3.See Owuor (2006), who discussed the pervasive nature of the fear of death among the Luo of Kenya and how such fear is widespread among Africans. See also Adeyemo the Luo of Kenya and how such fear is widespread among Africans. See also Adeyemo
(1997:60), who asserts that within African communities it is common for people to (1997:60), who asserts that within African communities it is common for peopl
believe that death ushers one's spirit into the spiritual world of the living dead. 
either as a narrative audience or the ideal narrative audience. Because of the need for credibility in the process of the search for meaning in the narrative of the passage in question, it follows to reason that the sociohistorical approach becomes necessary, especially because of the fact that it gives room to engage as far back as possible with the authorial audiences. The sociohistorical method validates an analytical approach towards understanding salvation in the sociohistorical religious milieu of the Greco-Roman world. It gives room for an analysis that places the author of Acts 16 together with the slave girl, the jailer and the present interpretive context into a conversation. ${ }^{4}$

Though it is possible to approach the text as the ideal narrative audience of the fourth category and place the interpretive task in safe waters, it could create further interpretive difficulties. Non-exploration from newer angles, as the sociohistorical method suggests, raises questions about the credibility of the interpretative process and perpetuates the feeling of distance and dislocation with the biblical material. When interpretation fails to place sufficient emphasis on the sociohistorical context in the search for meaning and rushes forward to the search for meaning from other interpretive angles, it creates perplexity and furthers suspicion, especially in African Christianity where people can readily and more easily identify with most of the biblical context ${ }^{5}$ and the narrative characters of the Bible. ${ }^{6}$ However, in disagreement with the radical suspicion with which postcolonial hermeneutics approaches the biblical material, exemplified by Dube (2000) and others, the history of the use and abuse of the Bible by some missionaries in the establishment of colonialism in Africa cannot be disputed. This reality further calls for the sociohistorical method, which reduces the distance between the text and the African reality through exploring contextual similarity and shared narratives, thereby stimulating the attitude of trust in the task of interpretation and the appropriation of meaning. In a departure from some existing approaches espoused within African theology and hermeneutics, ${ }^{7}$ the

4.This approach must not be confused with the 'reader response theory' of interpretation in which the modern-day reader or reading communities determine meaning with little or no careful regard to the author, the actual and the authorial audiences.

5.Ukpong (2000:11-28) and Adamo (2016) are among key African biblical scholars who have argued for contextual similarity between Africa and biblical times. Adamo (2016) goes further and extensively argues for the presence of Africa and Africans in the Bible and concludes that the Bible would have never been in the shape it is now without Africa and African participation in the drama of redemption. He maintains further that African biblical scholars continue to demonstrate the importance and influence of Africa and Africans in the Bible and that the Bible is not only an ancien Jewish document alone but also an African document (Bailey 1991:165-186; Cophe 1991:146-164; Felder 1991:127-145; Wimbush 2009:162-177). He usefully caveats his conclusion, though, that this is not to say that the Bible will cease to be meaningfu to a cultural group that fail to identify themselves in the Bible.

6.In her article on 'Style, narration, and salvation in urban Kenya', Brummel (2014) demonstrates the transformative power of embedded narrative in which sameness in the narratives (embedding a story within another) led to evident transformation. She maintains that ' $[\mathrm{b}] \mathrm{b}$ iblical stories embedded in contemporary Christian rhetoric, for example, encourage listeners to see a sameness between the here and now and a biblical space and time'.

7.See West (1997) and Speckman (2016) for notable exploration of key elements found in African biblical hermeneutics. While West places emphasis on the place of the 'real flesh and blood African reader' towards appropriating the text, Speckman proposes a 'celebration of life framework' as the way forward in African biblical hermeneutics. He elaborates his proposal as based on the teaching of indigenous hermeneutics. He elaborates his proposal as based on the teaching of indigenous
churches and the traditional (amaqaba) people. Both West and Speckman fail to churches and the traditional (amaqaba) people.
place scripture as central to the interpretive task. sociohistorical method keeps the scripture central to the interpretive task. ${ }^{8}$

\section{Salvation in Acts 16: Greco-Roman and African contextual similarities Greco-Roman context and salvation}

The narrative of Acts 16 is set against the backdrop of the wider Greco-Roman world of the first century. The Christian religion in the first century grew within the Greco-Roman context and actively engaged the cultures of its context (Hubbard 2013:103; Neufeld \& DeMaris 2010).

Kauppi (2006:16-18) describes the Greco-Roman religious context as a non-monolithic entity comprising Greek and Roman ritual practices, priests, temple attendants, oracles and also individual behaviours ('magic' and so-called popular religion, schools of thought [philosophy and mystical metaphysics such as Orphism], and localised cults). According to him, Greco-Roman religion could be described as the sum total of religious practices encountered by GrecoRomans in the daily course of their civic life. It is within such a religious context that their view of salvation must be understood. Greco-Roman religion revolved around cults and a pantheon of gods who had points of beginning in existence and possessed particular endowments and attributes for which their beneficiaries looked to them to provide. Depending on the attribute ascribed to a certain deity, benefactors expected such assistance from such a deity. Hubbard (2013:109) points out that 'in many ways, the mythology of the ancient Greeks represents a kind of primitive animism organised in a hierarchy and presented with a genealogy'. In essence, whether it was help, deliverance, a desired state of being or whatever was needed by a benefactor within the Greco-Roman religious framework, such a person would petition or look to any of the pantheon of gods that possessed the necessary attribute or endowment that could answer to such a need. Salvation was therefore understood to be available from a plurality of gods. In that setting, salvation is benevolence from the gods that could be displayed in rescue, care or healing, among many others things. These benefits could be obtained by offering sacrifices and appeasements to the deities.

The assumption that the notion of salvation in the GrecoRoman world is similar to the Christian concept of salvation is brought into question by Adluri (2013). From the perspective of Greek philosophy, Adluri asks:

What if Greek 'salvation' bespoke a radically different experience than the one we, influenced by over two millennia of Christian upbringing, have come to expect and associate with the term? (pp. 1-26)

8.See Magezi and Igba (2018) and Nyende (2005), who all argued about the normative place of the Bible in serving as the criterion for what is authentically Christian, which place of the Bible in serving as the criterion for what is authentically Christian, which compels all theologies that would wish to be considered Christian, including African theology, to inevitably come under the authority of the Bible for validation as Christian theology, maintaining that the centrality of the scripture in the African Christian theological endeavour should be sacrosanct. See also Meylahn (2009), who further explained the value of reading biblical narratives alongside modern-day narratives as a useful way of not only gaining better understanding of the biblical text but also 'keeping the affective power of the text to help construct identities and ethical roles'. 
Adluri's question bears weight. However, his claim that there is need to separate philosophy from theology in order to understand Greek notions of salvation fails to bear a similar impact. The fact that Greek notions of salvation were radically different from the biblical perspective is well supported, but he fails to find support in the line of argument that seeks to separate Greek philosophy and Greek religion. The idea that theology must be separated from philosophy in order to understand Greek notions of salvation is simply inconsistent with the Greco-Roman thought in which theology was inseparable from philosophy. The importance, however, of Adluri's question remains in the fact that it challenges wrongly held assumptions that salvation in Greco-Roman thought and Christianity may refer to one and the same thing. This brings to the fore the important fact that Greco-Roman understanding of salvation must not be assumed to speak of one and the same experience as in Christian theology.

Approaching a text such as Acts 16 therefore needs to be without the wrong assumption of similarity in meaning of such texts within their Greco-Roman settings and within Christian thinking, bearing in mind that a divergence in meaning and understanding could exist. Where such divergent meaning exists, it is important to explore and acknowledge such divergent meaning in the interpretive task. Exploring and acknowledging such divergent meaning makes room for credible reconstruction or making new meaning from the text. The converse is that where such pre-existing meaning of concepts is not explored and engaged in a credible way, the new meaning proffered could be an imposition that may be spurned sooner or later.

\section{African context and salvation}

Maluleke (2005:486) cautions that one should not pretend to speak comprehensively about Africa or the African context as if it were a single country. Admittedly, Africa is a vast, complex and widely diverse continent. There are, however, spectrums of belief and practices that spread across the continent, though with variations and particularities. A world of spirits and deities is one such belief. According to Nyende (2007:372), the religious cosmology of Africa is encompassed by spirit beings comprising ancestors, spiritancestors, spirits and deities. He explains that while some African communities like the Shona of Zimbabwe may have a simple, hierarchically ordered spirit world beginning with humans to ancestors and to the supreme deity, others like the Yoruba in south-west Nigeria have a very complex, hierarchically ordered spirit world with humans, ancestors, a horde of deities and the supreme deity at the top. Whether it is the simplified and straightforward belief and configuration of the spirit word among the Zimbabweans or the complicated format found among the Yoruba of Nigeria, the spirit world is common to Africa, though particularities in beliefs and practices relating to the spirit word might differ. Because of this widespread belief in the spirit world in Africa, sacrifices and appeasement of spirits in seeking individual and community well-being from the spirits, ancestors or deities is also commonplace.
Turaki (1999:257) further notes that salvation, immortality and human well-being are all tied to the ancestors and ultimately to the community in traditional Africa. Mbiti (1969:58-73) popularised the concept of 'the living dead' by theorising that such are dead or departed ancestors who are alive and have assumed a life that enables them to occupy the ontological position between spirits, men and God. The spirit-ancestors, according to him, are considered indispensable intermediaries in Africa. They are believed to be an integral part of the traditional African religious and social structure. Bujo (1992:22-25) particularly points out that the ancestor spirits are part of a mystical society and they possess the 'inalienable responsibility for protecting and prolonging the life of the community in all its aspects'. He adds that 'communion with the ancestors has both an eschatological and a salvation dimension'. He therefore notes that good health, numerous progeny, healthy cattle and abundant crops are all signs of the presence and the blessing of the ancestors. What Bujo attempts to do here is to attribute salvific and existential blessing to the mediation of the spirit-ancestors. One can infer that Bujo, in carefully couched words, attributes not only the mediation but the availability of salvific and existential blessing from and through the spirit-ancestors.

Essentially, salvation within such context can be summarised as individual or communal well-being, tied to spirits, ancestors, deities and the intermediary priests. Within African traditional religious framework, therefore, salvation is understood in some similar way to the Greco-Roman context, where salvation is known as benevolence or well-being received from a deity, whereby the deity is the source and the needed salvation is obtainable through sacrifices, appeasement and ensuring harmony with the gods and spirits.

\section{Lukan contextual awareness?}

We have examined the understanding of salvation within the Greco-Roman context and alongside the African contextual understanding about salvation. The question that remains is, how does Luke show contextual awareness in the narrative of Acts 16? This is important as we progress towards understanding his meaning of salvation that emerges from the narrative.

In Acts 16:16, Luke narrates that the girl who met Paul and his companion had a $\pi v \varepsilon \tilde{u} \mu \alpha$ Пv́$\theta \omega v \alpha$ [python spirit] by which she was able to tell fortunes as an oracle and through which she brought monetary gain to her masters. Such contextual facts in the Greco-Roman world find semblance in the African world, as discussed. In narrating the incidence, was Luke reporting an exorcism of an evil spirit as some interpreters have affirmed (Conzelmann 1987; Haenchen 1971); ${ }^{9}$ or was Luke showing an awareness and an engagement with the Greco-Roman culture and context in a specific way?

Luke's use of $\pi v \varepsilon \tilde{v} \mu \alpha$ [spirit] may not have particular significance, but the case is different with the use of Пv́ $\theta \omega v \alpha$ 9.For example, Bruce, Acts, p. 361; Johnson, Acts, pp. $297-98$ and C.K. Barrett, Acts (ICC; Edinburgh: T\&T Clark, 1998), II, 784-88. 
[Python]. In the Greco-Roman context, the practice of religion included the consultation of oracles in the temples, divination, astrology and magic. ${ }^{10}$ Among the key places with temples where such oracular activities were carried out was Delphi. In antiquity, Delphi was well known as the central oracular place for seeking divine revelation and guidance. Consulting the oracle on various issues concerning or relating to military campaigns, diplomacy, disputes or other personal issues was a common practice.

In a narrative history of Delphi, Scott (2014:7-30) claims that ' $\mathrm{t}$ ] he oracle and sanctuary of the Greek god Apollo at Delphi were known as the "omphalos" - the "centre" or "navel" - of the ancient world for more than 1000 years'. Scott further states that:

[i]ndividuals, city leaders, and kings came from all over the Mediterranean and beyond to consult Delphi's oracular priestess; to set up monuments to the gods in gold, ivory, bronze, marble, and stone; and to take part in athletic and musical competitions. (pp. 7-30)

The oracular function at the Delphi sanctuary was usually a role reserved for a female priestess, known as the Pythia, and she had to be a native of Delphi, otherwise known as a Delphian. The Greek god Apollo was known as the Supreme Being behind the oracular utterances, with the Pythia as the mouthpiece.

The question that arises is, did the Greco-Romans see the $\pi v \varepsilon v \tilde{\mu} \alpha$ Пv́$\theta \omega v \alpha$ as something bad from which the girl needed salvation or rescue through exorcism; furthermore, did the slave girl see herself in that light? The answer to this question will have a bearing on the implications that could come out of an interpretation of this text, especially for a modern reader. Suffice to say here that, in all likelihood, Luke's usage of the word Пú $\theta \omega v \alpha$ may not have been a new or strange concept to grasp or understand among the Greco-Roman audience. As Lightfoot (2014:219) points out, what Luke was doing in the narrative was using a language that connected to popular belief and culture.

Kauppi (2006:19-41) further adds from his study of GrecoRoman religions in Acts that the usage of the terms $\pi v \varepsilon \tilde{v} \mu \alpha$ $\Pi v \dot{\theta} \omega v$, especially in Acts 16, which translates to 'a python spirit', possibly alludes to the general oracular divination notions of the Greco-Romans and could form a basis of assuming that the Greco-Romans would have no problem seeing the action of the girl as originating in their well-known Greek inductive oracles and oracles of possession or inspiration.

Luke's contemporaries would have associated the Пú $\theta \omega v \alpha$ with a completely legitimate and beneficial form of religious activity, namely the provision of oracles. The reality of cosmic conflict between two powers, however, comes into focus through the reaction of Paul that led to the departure of the $\Pi v \dot{\theta} \omega v \alpha$. The reality of the term $\Pi v \dot{\theta} \omega v$ in particular being stretched and torn between its long history of positive meaning in pagan divinatory practice and its negative 10.Hubbard 2013:105-123. contextualisation in the present narrative also comes into sharp focus Klutz (2004:243-246). In the mention of the $\pi v \varepsilon \tilde{v} \mu \alpha$ Пv́$\theta \omega v \alpha$ and the ensuing exorcism, Luke's focus was not just the narration of an exorcism event. By invoking the name of Jesus over the $\pi v \varepsilon \tilde{u} \mu \alpha$ Пv́ $\theta \omega v \alpha$ [python spirit], as well as urging the jailer to believe in 'the Lord Jesus' for salvation, Luke was actually showing contextual awareness, engaging and challenging the understanding and everyday assumptions in the Greco-Roman world around him about the meaning and means of salvation.

\section{Salvation in Acts 16: The slave girl, jailer, Africa and Luke in conversation}

\section{The slave girl and salvation}

Oṽ̃นเ oi őv $\theta \rho \omega \pi$

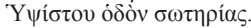

[These men are slaves of the Most High God, who proclaim to you a way of salvation.] (Ac 16:17)

The assertion made by the slave girl that Paul and his companion are slaves of the Theos Hypsistos (God Most High), who proclaim a way of Soteria (salvation), presents a familiar detail especially within the Greco-Roman context, which has drawn much debate among scholars. As Trebilco (1989) shows, the word v́ the New Testament, in Jewish pseudepigrapha and by other Jewish authors. The same word is, however, also used in classical literature and inscriptions of pagan deities, most frequently of Zeus. This has made scholars question the origin of the notion in order to reconstruct the slave girl's understanding in her usage of the word.

While Cook (1925), Roberts, Skeat and Nock (1936), Trebilco (1989) and others argue that the notion finds its origins in the syncretic and henotheistic ${ }^{11}$ nature of the ancient GrecoRoman religion, in which there exists belief in a supreme deity along with other deities, other scholars (Levinskaya 1996; Reimer 1995; Schürer 1897) argue that the origins are to be attributed to the theological influence of the early Jewish diaspora.

Through archaeological and epigraphic data analysis of the Theos Hypsistos, Tsalampouni (2011) rightly concludes that the cult of this deity, sometimes referred to as Zeus Hypsistos, originated in the Philippi region, as a high concentration of archaeological evidence shows. Dedicatory inscriptions found throughout Macedonia attest to the worship of this deity in the larger area of the Greco-Roman context. Therefore, when the slave girl declared Paul and Silas to be the slaves of the Theos Hypsistos who have come to show a way of salvation, she would not have contemplated the Jewish God, nor would her hearers.

Even though the title bears some similarity in reference to the Jewish God, its ambiguity of usage by the slave girl in

11.This notion fundamentally differs from monotheism in the sense that it holds to the belief in a supreme God without excluding belief in or the legitimising of the existence of other deities. 
Acts 16 and its reflection of the Greco-Roman henotheistic tendency, as pointed out earlier, which is in opposition to the Jewish unambiguous monotheistic ideas of God, strengthens the argument for a non-Jewish origin. Furthermore, it is highly unlikely that the actual and authorial Greco-Roman

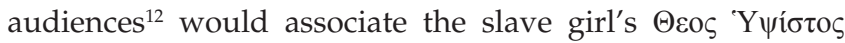
with the Jewish God.

As Rowe (2009:24) notes, there was every probability of the misidentification of the God of Israel with the highest god in the pantheon of local gods in the incidence of Acts 16:17, especially because such fusion, and interchangeability of the divine were commonplace in Greco-Roman antiquity at both the popular and philosophical levels. Though Christian readers of the Acts narrative then, and even now I may add, would be under no illusion as to the polytheistic nature of the slave girl's proclamation, it is within reason to imagine that the Gentile audience would have heard the slave girl's proclamation as a 'polytheistic interpretation of Christian proclamation', a way of conscripting the identity of God into the local religious tradition. The ensuing ambiguity, it appears, is what causes exasperation and the way of solving the exasperation, as verse 18 shows, is an invocation of the name of Jesus, unrelated to any of the known pantheon of divinities.

\section{The jailer and salvation}

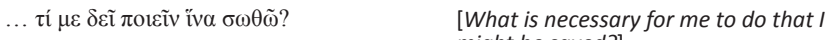 might be saved?] \\ (Ac 16:30)}

As a direct consequence of the slave girl's episode, Luke narrates that Paul and his companion were thrown into prison, where the jailer experienced an earthquake and thought the prisoners had escaped. He was apparently filled with fear from the experience of the earthquake and the possible repercussion of execution for letting prisoners escape under his watch. Luke narrates that the jailer was restrained by Paul from taking his life, which prompted his question about being saved. The jailer's question presents at least three possibilities that reflect his meaning and understanding of salvation. Firstly, it is possible that he views Paul and his companion as representatives of the gods, who can offer him salvation or deliverance (all implied in the same Greek word). In such a case, his question about salvation could mean a way of escape or deliverance from the apparent divine judgment signalled by the earthquake because of the common belief that an earthquake might disclose that the gods were displeased (Thomas 2011). The displeasure of the gods and the fear of death was a reality in his Greco-Roman context, similar to the African context as shown earlier.

Secondly, it is likely that he was familiar with Paul's teaching on salvation because it was actually the reason behind the imprisonment (Keener 1993). Polhill (1992:355) suggests that probably he had heard Paul's preaching or reports of his preaching but had not fully understood until then; or maybe he had fallen asleep to the sound of Paul and Silas's hymns to God and was now ready for understanding (Polhill 1992).

The third and more likely possibility can be seen in the answer he received to his question from Paul. The answer seems converse to the expectation of the jailer. The expected answer to 'What must I do?' should logically be followed by a list of things to do; an instruction to offer sacrifice to the gods would not be out of place. This expectation fits well with the GrecoRoman contextual background of salvation being available from the plurality of gods through offering sacrifices and appeasements. The answer was therefore unexpected and counter to the preconceived idea of the means of salvation. The jailer was pointed to a hitherto unknown 'Lord Jesus'. No sacrifices or offerings for appeasement were required. In this portion of the narrative, Paul challenges the jailer's preexisting view of salvation. It is not benevolence from the gods that could be displayed in rescue, care or healing; neither could it be obtained by offering sacrifices and appeasements to the deities. Paul's challenge to him was, '[b]elieve in the Lord Jesus and you will be saved'. His concern about death was a spiritual concern as much as it was also a physical or temporal concern. Salvation by believing in Jesus answers both concerns.

\section{Africa and salvation}

In showing the contextual similarities that warrant the inclusion of Africa in this conversation, we have earlier discussed the contextual framework and the emerging understanding of the meaning of salvation in Africa and will not rehash the details here. ${ }^{13}$ Suffice to recap that within an African traditional religious framework, salvation is known as individual or communal well-being. It is received from a deity, whereby the deity is the source and the needed salvation is obtainable through intermediaries by offering sacrifices, appeasement or ensuring harmony with the gods and spirits.

Brand (1999) helpfully categorises notions of salvation found within African Christianity as follows:

- anthropological (based on human good)

- social (tending towards salvation as corporate or common good)

- cultural (salvation as a form of cultural constellation or inculturation)

- ontological (defining salvation as a transformation of the ontological structures of the world)

- vitalistic (seeing salvation as a transmission of vital force or life force). (pp. 193-223)

From Brand's categorisation and the earlier discussion on the contextual understanding in Africa, it is apparent that a pre-existing notion of salvation is present; such notions, however, similar to notions found in the Greco-Roman understanding, are faulty, not necessarily in the expectation of what salvation entails but in the means of salvation that 13.See preceding discussion on African context and salvation. 
accommodates sacrifices and appeasements to gods and spirits as the source of the desired salvation.

\section{Luke and salvation: 'In the name of Jesus Christ' and 'Believe in the Lord Jesus'}

The concern here is not to get into the scholarly debate about Lukan salvation. ${ }^{14}$ It is sufficient to say that the Lukan salvation theme is interrelated between the Gospel and Acts components, which makes it multifaceted. Within the facet of Acts 16, Luke defines salvation through the two incidences of the slave girl and the jailer. During the encounter with the slave girl, Luke narrates an invocation of the name of Jesus Christ. In answer to the jailer's question, believing in the Lord Jesus was put forward in response. Without speculation, Jesus is central to Luke's salvation. Luke defines salvation by showing that salvation is spiritual intervention with possible physical ramifications, as opposed to an understanding of salvation that is spiritualised only. This view does not discard the eschatological reality of Lukan salvation; rather it accommodates that reality in the spiritual dimension of Luke's definition of salvation. For the Philippian jailer in particular, some have noted (Krodel 1986:313) the eschatological reality of salvation in joy experienced and expressed as a result of being saved. ${ }^{15}$

Luke shows that salvation entails a spiritual and divine act demonstrated in 'the setting at liberty' of the slave girl from the oracular burden of the $\pi v \varepsilon \tilde{v} \mu \alpha \Pi v \dot{\theta} \omega v \alpha$ as well as economic exploitation. Luke further shows salvation as freedom from the fear of death such as expressed by the Philippian jailer. The jailer and the slave girl's need for salvation were both spiritual and temporal. Luke's definition of salvation is in line with the salvation mission of Jesus as pointed out by Luke in the fourth chapter of his Gospel component. This speaks directly into the world view of Luke's audience. It also speaks into the world view of Africans. By showing this meaning, Luke challenges the understanding about the means of obtaining salvation. Money is not involved and neither is material sacrifice to the gods or God. It is also not obtainable from sacrifices to the plurality of gods, as the unexpected response to the question of the jailer about what needs to be done to receive salvation shows. What Luke essentially does in defining salvation in this way is challenge prevailing thinking.

Luke makes it clear that salvation is synonymous with Jesus. Jesus is salvation. Salvation is not from their Theos Hypsistos or from the gods. Further, salvation is not related to money nor any humanly offered sacrifice to be obtained. It is attained by invoking and believing in the name of Jesus. This is new to Greco-Romans and Africans. It is new to every culture where the message of salvation is advancing into pre-existing notions about the meaning and means of salvation.

14.Mchunu (2013) engages some Luke-Acts scholars and presents a concise discussion on arguments about Lukan salvation that lies outside the scope of this paper.

15.A further discussion on the eschatological reality of Lukan salvation falls outside the confines of the narrative.

\section{Missional and apologetic implications}

Stoker (2017:192) describes different apologetic methods suitable for different circumstances. He points out two basic approaches, namely defence and attack. He shows how both approaches were used by Paul in 2 Corinthians 10:3-5. Both apologetic approaches are evident in Acts 16 in Paul's confrontation of the spiritual and temporal powers and the defence of the Gospel through his proclamation of the message of salvation. Earlier on, we showed the contextual similarity between the African context and the Greco-Roman context (including the slave girl and the jailer), which Luke addresses. It falls within reason, therefore, to suggest the following as the missional and apologetic implications drawn from Acts 16 into the African context.

\section{Missional implication}

\section{Transformational mission}

The narrative of Acts 16 presents a missionary vision that displays the transformative power of the message of salvation. For the slave girl, though we do not hear more of her, it is safe to assume that from being an exploited slave who made money for her owners, she became at least free from the oracular burden of the spirits and probably became part of the growing numbers of believers. We can assume that the jailer went from being a man bound by the fear of death from the wrath of the gods to a joyful member of the growing community of believers. Luke points us to mission that is transformative in the lives of individuals and breaks down barriers of class and race with the example of a nameless slave girl and possibly a high Roman military official, who all demonstrate how God breaks down dividing barriers and can unite people of very different kinds in Jesus Christ (Stott 1994:262).

\section{Transcendental mission}

'Transcendental' here is not used in the eastern meditation mystical sense. Rather, it is used in the etymological sense of the word. Luke in Acts 16 points us to the need for mission that is aware of the spirit world of Africans. Such mission does not shy away from invoking the name of Jesus against such deceptive spirit voices where need be. Indeed, such mission must make clear to the community of Christ followers that there is no need to be afraid of those powers because salvation in Jesus entails the derivative authority of Jesus. Paul's authority was derived from Jesus, who has all authority and makes it available to his followers.

\section{Transcultural mission}

Closely related to the transcendental implication is the transcultural implication. Luke shows the vision of mission that is very aware of what is generally accepted and considered a harmless part of culture. Oracular divination, for instance, had become part of the culture and was not perceived as wrong. The message of salvation must aim to transform culture through world view change. The message of salvation needs to take root in the culture but transcend 
and transform the culture into a new culture, a culture tied to Jesus, through his word today. Whereas transformational mission aims at individuals, transcultural mission should aim at transforming cultural norms that reinforce wrong understanding of salvation. Another implication for mission is the need to proclaim the message of salvation that reflects the Lukan definition in Acts 16, which is salvation that is spiritual with possible physical ramifications. Salvation that can answer to temporal fears, like the fear of death or fear of spirits, speaks into the pre-existing religious framework of Africans. When Africans are presented with salvation that answers their spiritual need and leaves out their temporal fears and concerns, it creates room for the search of an alternative means that will answer those fears, leading to syncretism. Presenting salvation as Luke defines it does not detract from the eschatological fullness of salvation, as we have argued earlier.

\section{Apologetic implication}

\section{Confronting legal barriers}

Mission must not turn a blind eye to injustice and illegality. Luke shows this through the insistence of the missionaries in Acts 16 on their legal right to fair trial. Leveraging on the legal system in the advance of the message of salvation in Acts $16: 34-40$ is another implication that can be drawn. Legal avenues must be explored more actively, for instance, by way of insisting on the freedom of speech for citizens, especially in parts of Africa where this is not the case. Constitutional provision for the freedom of speech and the practice of Christian religion must be defended, especially among minority Christian communities. Legal provisions that unjustly limit the expansion of the message of salvation must be challenged.

\section{Confronting intellectual barriers}

According to Rowe (2009:21), Luke's call through the mouth of Paul is not simply an admonition to tweak a rite or halt a ceremony. It contains, rather, the summons that simultaneously involves the destruction of an entire mode of being religious. The missionaries in Acts 16 challenged the philosophical and intellectual foundations of the culture, bearing in mind that Greco-Roman religion was tied to philosophy. In the advance of the message of salvation, there must be readiness to confront intellectual barriers in whichever form they present themselves against the advance of the message of salvation.

\section{Confronting deceptive barriers}

In Acts 16, the deceptive barriers were represented by a Pythia who offered divination for money. In present-day Africa, it is false prophets who offer divination as prophecy, for monetary gain. Luke shows the need to challenge such deception, even if it is one slave girl at a time. Luke shows the need for mission that is perceptive and able to respond appropriately to the proclamation of salvation that is deceptive, possibly confusing and monetarily driven. True proclaimers of the message of salvation need to be ready for such a world view confrontation. Effective apologetic methods to counter and combat such activities need to be developed.

\section{Conclusion}

Luke defines salvation by showing that salvation is spiritual intervention with possible physical ramifications, as opposed to an understanding of salvation that is spiritualised only. This speaks directly into the world view of Luke's audience. It also speaks into the world view of Africans. In obtaining this salvation, money is not involved and neither is material sacrifice to the gods. What Luke essentially does in defining salvation in this way is challenging the prevailing thinking. Luke challenges the faulty Greco-Roman understanding of salvation and by extension, the faulty African understanding of salvation, and he provides an alternative.

Luke makes it clear that salvation is synonymous with Jesus. Jesus is salvation. Salvation is not from the Theos Hypsistos or other plurality of gods. It is attained by invoking and believing in one name, the name of Jesus. This is new to Greco-Romans and Africans because Jesus is not listed among their pantheon of deities. It is new to every culture where the message of salvation is advancing into pre-existing notions about the meaning and means of salvation.

\section{Acknowledgements Competing interests}

The authors declare that they have no financial or personal relationships that may have inappropriately influenced them in writing this article.

\section{Authors' contributions}

Both authors equally contributed to the writing of this article.

\section{References}

Adamo, D.T., 2016, 'African biblical studies: Illusions, realities and challenges', In die Skriflig 50(1), a1972. https://doi.org/10.4102/ids.v50i1.1972

Adelakun, A.J., 2011, 'A theological reflection on Mbiti's conception of salvation in African Christianity', Nebula 1, 25.

Adeyemo, T., 1997, Salvation in African tradition, 2nd edn., Evangel, Nairobi.

Adluri, V., 2013, Philosophy and salvation in Greek religion, De Gruyter, Boston, MA.

Bailey, R.B., 1991, 'Beyond identification: The use of Africans in the Old Testament poetry and narratives', in C.H. Felder (ed.), Stony the road we trod, pp. 165-186, Fortress, Minneapolis, MN.

Balcomb, A., 2011, 'A hundred miles wide, but only a few inches deep! Sounding the depth of Christian faith in Africa', Journal of Theology for Southern Africa 140, 20-33.

Barrett, C.K., 1998, A critical and exegetical commentary on the Acts of the Apostles, vol. II, T\&T Clark, Edinburgh.

Bovon, F., 2006, Luke the theologian: Fifty-five years of research (1950-2005), Baylor University Press, Waco, TX.

Brand, G., 1999, 'Salvation in African Christian theology: A typology of existing approaches', Exchange 28(3), 193. https://doi.org/10.1163/157254399x00014

Brummel, E.J., 2014, 'You don't have to pray to somebody in special English: Style, narration, and salvation in urban Kenya', Journal of Religion in Africa 44(2), 251-281. https://doi.org/10.1163/15700666-12340006

Bujo, B., 1992, African theology in its social context, Orbis Books, Maryknoll.

Copher, C., 1991, 'Black presence in the Old Testament', in C.H. Felder (ed.), Stony the road we trod, pp. 146-164, Fortress, Minneapolis, MN.

Conzelmann, H., 1987, Acts, Hermeneia, Fortress Press, Philadelphia, PA, p. 131. 
Cook, A., 1925, Zeus: A study in ancient religion, vol. 2, pt. 2, Cambridge University Press, Cambridge.

Dube, M.W. \& West, G. (eds.), 2000, The Bible in Africa: Transactions, trajectories, and trends, Brill, Leiden.

Felder, C., 1991, 'Race, and biblical narratives', in C.H. Felder (ed.), Stony the road we trod, pp. 127-145, Fortress, Minneapolis, MN.

Garrett, R.S., 1992, 'Sociology of early Christianity', in D.N. Freedman (ed.), The Anchor Bible dictionary, Doubleday, New York.

Green, J.B., 2010, Methods for Luke, Cambridge University Press, New York.

Haenchen, E., 1971, The Acts of the Apostles: A Commentary, Westminster, Philadelphia, PA, pp. 495-496.

Hubbard, M.V., 2013, 'Greek religion', in J.B. Green \& L.M. McDonald (eds.), The world of the New Testament: cultural, social, and historical contexts, pp. 105-123, Bake Academic, Grand Rapids, MI.

Magezi, C. \& Igba, J.T., 2018, 'African theology and African Christology: Difficulty and complexity in contemporary definitions and methodological frameworks', HTS Theological Studies 74(1), 4590. https://doi.org/10.4102/hts.v74i1.4590

Isizoh, D.C., 1998, A reading of the Areopagus speech (Acts 17, 22-31) from the African traditional religious perspective', African Christian Studies 14(2), 1-25.

Jenkins, P., 2002, The next Christendom: The coming of global Christianity, Oxford University Press, Oxford.

Kauppi, L.A., 2006, Foreign but familiar Gods: Greco-Romans read religion in Acts, T \& T Clark International, London.

Keener, C.S., 1993, The IVP Bible background commentary: New Testament (Acts 16:29-30), InterVarsity Press, Downers Grove, IL.

Klutz, T., 2004, The exorcism stories in Luke-Acts: A sociostylistic reading, Cambridge University Press, Cambridge.

Krodel, 1986, Acts, Fortress Press, Philadelphia, PA, p. 313.

Levinskaya, I., 1996, The book of Acts in its diaspora setting, Eerdmans, Grand Rapids. Lightfoot, J.B., 2014, The Acts of the Apostles: A newly discovered commentary, IVP Academic, Downers Grove, IL.

Malherbe, A.J., 1983, Social aspects of early Christianity, Fortress Press, Philadelphia, PA.

Maluleke, T.S., 2005, 'African theology', in D. Ford \& R. Muers (eds.), The modern theologians: An introduction to Christian theology since 1918, Blackwell, Malden, MA.

Manus, C.U., 1985, 'The Areopagus Speech (Acts 17: 16-34): A study of Luke's approach to evangelism and its significance in the African context', Africa Theological Journal 14(1), 13.

Marshall, I.H., 1971, Luke: Historian and theologian, Zondervan, Grand Rapids, MI.

Mbiti, J.S., 1969, African religions and philosophy, Praeger, New York.

Mbiti, J.S., 1986, Bible and theology in African Christianity, Oxford University Press, Nairobi.

Mchunu, L.N., 2013, 'The meaning of salvation in Luke-Acts: An enquiry into Luke's understanding of salvation', Master's thesis, North-West University, Potchefstroom.

Meeks, W.A., 2003, The first urban Christians: The social world of the apostle Paul, 2nd edn., Yale University Press, New Haven, CT.

Meylahn, R., 2009, 'Narrative-critical approach as hermeneutical framework for a creative dialogue between biblical sources and secular extra-biblical sources: The Lord of the Rings as an entry into the Book of Revelation', Verbum et Ecclesia 30, Lord of the Rings as an entry into the Book of
174-201. https://doi.org/10.4102/ve.v30i1.70

Neufeld, D. \& DeMaris, R.E., 2010, Understanding the social world of the New Testament, Routledge, London.

Neyrey, J.H., 1991, The social world of Luke-Acts: Models for interpretation Hendrickson, Peabody, MA.

Nyende, P., 2005, 'Jesus the greatest ancestor: A typology-based theological interpretation of Hebrews' Christology in Africa', PhD dissertation University of Edinburgh, Edinburgh.
Nyende, P., 2007, 'Hebrews' Christology and its contemporary apprehension in Africa', Neotestamentica 41(2), 361-381.

Onwu, N., 1988, 'Ministry to the educated: Reinterpreting Acts 17:16-34 in Africa', African Christian Studies 4(4), 61-71.

Owuor, V.B., 2006, 'Resurrection hope in the African context: Challenging Luo beliefs and practices concerning death', M.A. (Dogmatics), North-West University, Potchefstroom Campus.

Polhill, J.B., 1992, Acts, vol. 26, Broadman \& Holman, Nashville, TN.

Rabinowitz, P.J., 1977, 'Truth in fiction: A reexamination of audiences', Critical Inquiry 4(1), 121-141. https://doi.org/10.1086/447927

Reimer, I.R., 1995, Women in the Acts of the Apostles: A feminist liberation perspective, Fortress Press, Minneapolis, MN.

Roberts, C.H., Skeat, T.C. \& Nock, A.D., 1936, 'The gild of Zeus Hypsistos', Harvard Theological Review 29(1), 39-88. https://doi.org/10.1017/S0017816000 033198

Rowe, C.K., 2009, World upside down: Reading Acts in the Graeco-Roman age, Oxford University Press, Oxford.

Schürer, E., 1897, A history of the Jewish people in the time of Jesus Christ, T. \& T. Clark, Edinburgh.

Scott, M., 2014, Delphi: A history of the center of the ancient world, Princeton University Press, Princeton, NJ.

Speckman, M., 2016, 'African biblical hermeneutics on the threshold? Appraisal and way "forward"', Acta Theologica 36, 204-224.

Speckman, M.T., 1999, Alms or legs?: A contextual reading of Acts 3:1-10 in the light of an alternative theory of human development, Unisa, Pretoria.

Stoker, H.G., 2017, 'Facing the apologetic challenges of contemporary scientific atheism', Unio cum Christo 3(2), 185-201.

Stott, J.R., 1994, The message of Acts: The Spirit, the church and the world, Inter-Varsity Press, Leicester.

Talbert, C.H., 2003, Reading Luke-Acts in its Mediterranean milieu, Brill, Boston, MA.

Thomas, D.W., 2011, Acts, in R.D. Phillips, P.G. Ryken \& D.M. Doriani (eds.), Reformed Expository Commentary Series, P\&R Publishing, Phillipsburg, NJ.

Trebilco, P.R., 1989, 'Paul and Silas-Servants of the Most High God (Acts 16.16-18)', Journal for the Study of the New Testament 11(36), 51-73. https://doi. org/10.1177/0142064X8901103604

Tsalampouni, E., 2011, The cult of Theos Hypsistos in Roman Thessalonica and the first Christian community of the city, SBL International Meeting, London, July 07 2011.

Turaki, Y., 1999, Christianity and African gods: A method in theology, Potchefstroomse Universiteit vir $\mathrm{CHO}$, Potchefstroom.

Ukpong, J., 2000, 'Development in biblical interpretation in Africa: Historical and hermeneutical directions', in G. West \& M. Dube (eds.), Bible in Africa, pp. 11-28, Brill, Boston, MA.

Walls, A.F., 2002, The cross-cultural process in Christian history, Orbis Books, Maryknoll, NY.

West, G., 2008, Biblical hermeneutics in Africa, UKZN Ujama Centre, viewed 05 February 2017, from http://www.chora-strangers.org/files/chora/west2008_ Parratt.pdf

West, G. \& Dube, M. (eds.), 2000, Bible in Africa, Brill, Boston, MA.

Wimbush, V., 2009, 'Scripture for strangers: The making of an Africanized Bible', in T.-S Liew (ed.), Postcolonial interventions, pp. 162-177, Sheffield Phoenix Press, Sheffield.

Winter, B.W. \& Clarke, A.D. (eds.), 1993, The Book of Acts in its first-century setting The Book of Acts in its ancient literary setting, Eerdmans, Grand Rapids, MI.

Witherington, B., 1998, Salvation and health in Christian antiquity: The soteriology of Luke-Acts in its first century setting, Eerdmans, Grand Rapids, MI. 